Litteratur

. Smebye KL, Granum S, Wyller TB et al. Medisinske funn i en tverrfaglig geriatrisk fallpoliklinikk. Tidsskr Nor Legeforen 2014: 134: 705-9.

2. Korhonen N Niemi S, Palvanen M et al. Declining age-adjusted incidence of fall-induced injuries among elderly Finns. Age Ageing 2012; 41: 75-9.

3. Stel VS, Smit JH, Pluijm SM et al. Consequences of falling in older men and women and risk factors for health service use and functional decline. Age Ageing 2004; 33: 58-65.

4. Roksund G. Falltendens hos eldre. Tidsskr Nor Legeforen 2014: 134: 688.

5. Gregg EW, Pereira MA, Caspersen CJPereira MACaspersen CJ. Physical activity, falls, and fractures among older adults: a review of the epidemiologic evidence. J Am Geriatr Soc 2000; 48: 883-93.

6. Gillespie LD, Robertson MC, Gillespie WJ et al. Interventions for preventing falls in older people living in the community. Cochrane Database Syst Rev 2012; 9: CD007146.

7. Palvanen M, Kannus P, Piirtola M et al. Effectiveness of the Chaos Falls Clinic in preventing falls and injuries of home-dwelling older adults: a randomised controlled trial. Injury 2014: 45: 265-71.

8. Kanis JA, McCloskey EV, Johansson $\mathrm{H}$ et al; Scientific Advisory Board of the European Society for Clinical and Economic Aspects of Osteoporosis and Osteoarthritis (ESCEO) and the Committee of Scientific Advisors of the International Osteoporosis Foundation (IOF). European guidance for the diagnosis and management of osteoporosis in postmenopausal women. Osteoporos Int 2013; 24: $23-57$.

\section{Mellingsæter svarer:}

Vi er enige med Johan Halse i at osteoporose er en svært viktig årsak til de sørgeligste resultatene av fall.

En vurdering av om det foreligger osteoporose og om det er aktuelt å henvise til bentetthetsmåling, hører med i en fallpoliklinikk. Vår erfaring er også at mange har en osteoporosediagnose fra tidligere, men uten at de får anbefalt behandling. Dette er en del av forklaringen på at så mange som $21 \%$ av pasientene fikk D-vitamin, eventuelt med kalsium, ved fallpoliklinikken, slik vi skriver i tabell 4 (1). Både kalsium/vitamin D, bisfosfonater og hoftebeskyttere er tiltak vi vurderer, men siden temaet for artikkelen var utredning av årsaker til fall, ble det ikke betont så sterkt.

\section{Marte Mellingsæter}

cmelling@online.no

Marte Mellingsæter (f. 1973) er lege ved geriatrisk avdeling, Oslo universitetssykehus

Ingen oppgitte interessekonflikter

\section{Litteratur}

1. Smebye KL, Granum S, Wyller TB et al. Medisinske funn i en tverrfaglig geriatrisk fallpoliklinikk. Tidsskr Nor Legeforen 2014; 134: 705-9.

\section{Re: PSA-måling og prostatakreft - overdiagnostisering og overbehandling?}

Breidablik og medarbeideres artikkel (1) er betimelig nå som professor Richard Albin, mannen som oppdaget PSA-testen, har skrevet bok og erklært at PSA ikke er en god indikator for cancer prostatae, og i mange tilfeller ikke burde vært brukt for dette formål (2). Debatten er ikke ny. I 1978 kjørte magasinet Der Spiegel en serie artikler om kreft med tittelen «Ingen angst for kreft» signert professor Julius Hackenthal (3). Her tas troverdigheten av kreftdiagnostikk opp, herunder bruken av mikroskop ved analyse av celler fra antatt prostatakreft. Konklusjonen er nedslående: Selv med elektron-mikroskopi var ikke diagnostikken av kreftceller hos dyr og mennesker entydig. Hva angår prostata var opptil $20 \%$ av protstakjertlene infiserte, og muligens var det da infeksjonsendringer man mistolket som kreft.

Debatten om korrekt diagnostikk er absolutt betimelig og er parallell til debatten om borreliose som verserer for tiden. I denne sammenheng har jeg som lege og forfatter drevet et toårig journalistisk arbeid som har resultert i en bok om flåttbårne sykdommer, der jeg har forsøkt å bringe klarhet i hvor troverdige diagnoser er
(4). Man har her en helt parallell situasjon til prostatakreft: Usikre serologiske tester og konflikter med mikroskopi. Som tidligere fysikkstudent ser jeg også parallellsituasjonen til fysikk: I teknologiens gråsone der våre identifaktorer for gjenkjennelse ikke lenger er entydige, inntrer Werner Heizenbergs usikkerhetsprinsipp, som sier at den som undersøker med sin metode vil påvirke det man undersøker så mye at entydighet i konklusjon om erkjennelse forsvinner. I atomfysikk lever man med dette. Kan vi leger leve med det? Og hva med pasientene? Og når situasjonen er usikker, er det vår angst for å skulle overse og ikke behandle kreft på et tidlig stadium som får oss til å «se» kreft der det ikke finnes med påfølgende feilbehandling? Er tiden moden for økt erkjennelsesteoretisk kunnskap og mer inngående selvransakelse (5)?

Bjørn Johan Øverbye

bjorn@dr-overbye.no

Bjørn Johan Øverbye (f 1947) er lege ved Arendal helsesenter AS Ingen oppgitte interessekonflikter

Litteratur

1. Breidablik HJ, Meland E, Aakre KM et al. PSA-måling og prostatakreft - overdiagnostisering og overbehandling? Tidsskr Nor Legeforen 2013; 133: 1711-6.

2. Albin RJ. The great prostate hoax: How big medicine hijacked PSA test and caused a public health disaster. NewYork: Palgrave MacMillian, 2014.

3. Hackenthal. Kein Angst für Krebs, Der Spiegel, 43/1978 s: 208-218.

4. Øverbye BJ. Flåttbårne sykdommer. Fevik: Veiviseren forlag, 2014

5. Dilts R, Hallbom T, Smith S. Beliefs. Portland: Metamorphous Press, 1990

\section{Re: Vitamin D - hvor mye er nok, og er mer bedre for helsen?}

Brustad \& Meyer (1) og Dahl \& Thorsby (2) gjør godt rede for sitt nøkterne syn på måling og vurdering av vitamin D-status. Vi er enige $i$ at en serumkonsentrasjon av 25-hydroksyvitamin D på $50 \mathrm{nmol}$ per liter sannsynligvis er tilstrekkelig for de fleste (1). Som forfatterne påpeker, er imidlertid dette kontroversielt. Vitamin D kan ha immunmodulerende effekter. Verdier av 25-hydroksyvitamin D mellom 75 og $125 \mathrm{nmol}$ per liter er forbundet med lav sykdomsrisiko og sykdomsaktivitet ved multippel sklerose (3), er bra for beinhelsa og er ikke toksiske. Inntil overbevisende resultater av randomiserte studier foreligger, vil vi anbefale dette serumnivået til personer med multippel sklerose.

Et viktig moment som ikke omtales, er at serumnivået av 25hydroksyvitamin D antagelig varierer betydelig gjennom året, $i$ hvert fall hos personer som ikke bruker tilskudd om vinteren. Repetert måling hos 88 personer med multippel sklerose gjennom to år viste at de laveste nivåene vanligvis ble nådd i mars/april, og var under halvparten av toppnivået i august/september (3). En person med «tilfredsstillende» nivå av 25-hydroksyvitamin D på $50 \mathrm{nmol}$ per liter i august, har sannsynligvis uttalt mangel på ettervinteren og våren. Disse målingene ble utført før interessen for vitamin D «tok av», hos personer som var instruert til ikke å bruke tran, og som var lite preget av sykdommen. De er derfor sannsynligvis nokså representative for store deler av befolkningen som ikke bruker store doser vitamin D-tilskudd. På grunnlag av disse dataene laget vi en "vitamin D-kalkulator", der man ved å plotte inn ett enkelt nivå og måletidspunkt, får estimert personens vitamin Dstatus gjennom året (4). Kalkulatoren er tilgjengelig på hjemmesiden til Akershus universitetssykehus (5).

Hvordan bør klinikere forholde seg? Personer med en alminnelig sunn livsstil og som spiser fisk regelmessig eller bruker vitamin Dtilskudd /tran, trenger ikke å måle sitt 25-hydroksyvitamin D-nivå. Dersom man først måler 25-hydroksyvitamin D, for eksempel hos personer med kronisk sykdom og risiko for mangel, må måletidspunktet tas i betraktning. Følgende tommelfingerregel kan brukes: 
Målinger utført i februar-april gjenspeiler sannsynligvis bunnivået. Målinger utført på sensommeren er sannsynligvis rundt det dobbelte av bunnivået. Ved måling mellom disse periodene må man bruke skjønn, gjerne også «vitamin D-kalkulatoren».

\section{Trygve Holmøy}

trygve.holmoy@medsisin

Kristin Løken-Amsrud

Margitta T. Kampman

Øivind Torkildsen

Kjell-Morten Myhr

Trygve Holmøy (f. 1960) er overlege og professor ved nevroklinikken på Akershus universitetssykehus.

Ingen oppgitte interessekonflikter

Kristin Løken-Amsrud (f. 1979) er lege i spesialisering ved nevrologisk avdeling ved Sykehuset innlandet.

Ingen oppgitte interessekonflikter

Margitta T. Kampman (f. 1962) er overlege og førsteammanuensis ved nevrologisk avdeling, Universitetssykehuset i Nord-Norge.

Ingen oppgitte interessekonflikter

Øivind Torkildsen (f. 1979) er lege i spesialisering og postdoktorstipendiat ved nevrologisk avdeling. Haukeland universitetssykehus.

Ingen oppgitte interessekonflikter

Kjell-Morten Myhr (f. 1963) er professor og overlege ved Nevrologisk avdeling, Haukeland universitetssykehus.

Ingen oppgitte interessekonflikter

\section{Litteratur}

1. Brustad M, Meyer HE. Vitamin D - hvor mye er nok, og er mer bedre for helsen? Tidsskr Nor Legeforen 2014; 134: 726-8.

2. Dahl SR, Thorsby PM. Hvordan måle vitamin D-status? Tidsskr Nor Lægeforen 2014: 134: 729-31.

3. Løken-Amsrud KI, Holmøy T, Bakke SJ et al. Vitamin D and disease activity in multiple sclerosis before and during interferon- $\beta$ treatment. Neurology 2012; 79: 267-73.

4. Saltyt? Benth J Myhr KM Løken-Amsrud Kl et al. Modelling and prediction of 25-hydroxyvitamin D levels in Norwegian relapsing-remitting multiple sclerosis patients. Neuroepidemiology 2012; 39: 84-93.

5. Vitamin D kalkulator: Beregn vitamin D-nivået for hele året fra en måling. www.ahus.no/aktuelt/nyheter/Sider/vitamin-d-kalkulator.aspx (26.4.2014)

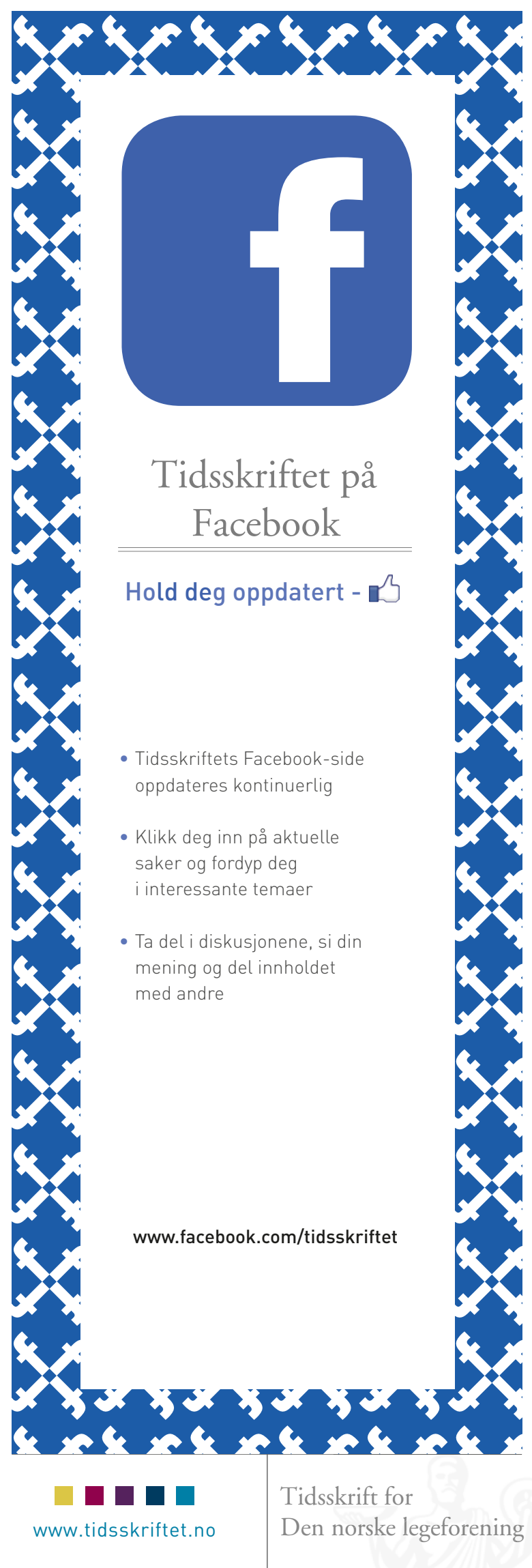

